\title{
SOME OBSERVATIONS ON THE LIFE HISTORY \\ OF STROPHITUS EDENTULUS
}

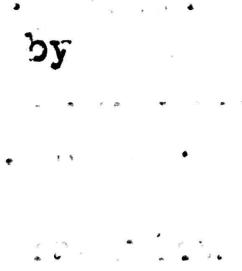

Earl Albert Martin, A.B.

\section{SUBMITTED IN PARTIAL FULFILMENT OF THE \\ REQUIREMENTS FOR THE DEGREE OF \\ MASTER OF ARTS}

in the

GRADUATE SCHOOL

of the

UNIVERSITY OF MISSOURI 
SOME OBSFRVATIONS ON THF LIFE HISTORY OF STROPHITUS EDENTULUS

1. Introduction - 1 .

2. The Life History of a Typical Fresh Water Mussel -.....- 1.

3. Description of Strophitus edentulus -

4. Metamorphosis without Parasit1sm - 3.

5. Metamorphosis with Parasit1sm - 10.

A. Observations on Strophitus toward close of breeding season -

B. Observations on Strophitus at beginning of breeding season - 14 .

6. Conclusions - 16.

7. Bibllography - 19.

8. Key to Abbreviations in Plates

9. Explanation of Plater 10. Platea I - XIV. (F1gs. 1-36) 
SOME OBSERVATIONS ON THE LIFE HISTORY OF STROPHITUS EDENTULUS

\section{INTRODUCT ION}

Stroph1tus edentulus is a fresh water mussel which has been sald to go thru its metamorphosis both as a parasite on fish (Howard 1914) and without parasitism (Lefevre and Curtis I912). Th1s condition in Strophitus is rendered more interesting by the fact that there is but one other exception to the parasitic habit among the fresh water mussels.This exception, Anodonta imbec11218 (Say), is one of the hermaphroditic species and is not closely related to Strophitus.Since these two species are widely separated In structure, and since the same changes are occuriting in each form,1t is possible that we have here a case of convergent evolution, the investigation of which may throw some light on the nature of this most interesting adaptation of the fresh water mussels. In the following paper I have presented a review of the observations and experiments from which the above conclusions were drawn,together with some additional data which I have collect-ed myself and a discussion of certain uncompleted and unpublished work which was placed in my hands.

\section{THE LIFE HISTORY OF A TYPICAL FRESH TATER MUSSEL}

The life hlstory of a typlcal fresh water museel such as Lampo1118 anodontoldes is as follows: The sexes are separate, the gonads being located in the dorsal region of the foot. When these are mature the genital products escape to the inner suprabranohlal chamber.In the males the spermatozoa escape with the excurrent water, but in the females when the egge reach the cloaca the ourrent of water 1s reversed so that they are carried backward into 
the outer suprabranchial chamber and drop down into the watertubes.Fertilization may take place at any time after the eggs reach the suprabranchial chambers, the spermatozoa being carried in with the incurrent water, and passing thru the ostia of the g1ll lamellae. Shortly after the eggs drop into the water-tubes they are bound together with an agglutinating substance and the superficial water-tubes are formed. Development proceeds to a larval stage known as the glochidium. The glochldium is composed of two symmetrical valves held together by a huge central adductor muscle which is covered with a layer of embryonic mantle cello.Aside from the precoclously developed shell, the only indication of the adult organs is a mass of darkly staining cells located near the poaterior end (Fig.1). When the glochidia are mature the adductor begins to contract spasmodically, and shortly after this the masses of glochidia are extruded thru the exhalent siphon of the parent. At this point the development stops unless they become attached to the fin or gill of a fish. In case this occurs the tissues of the fish, which come in contact with the glochidium hypertrophy, so that they soon inclose the glochldium within a cyst. Whether they derive nourishment from the fish or not is a disputed point, but at any rate the central adductor muscle soon disappears and the organs of the adult are formed; whereupon the cyat breaks,releasing the clam which is now ready to begin its life on the bottom.

\section{DESCRIPTION OF STROPHITUS EDENTULUS}

Strophitus edentulus is of medium size averaging about eight and one-half centimeters long by four and one-half centimeters wide. The males and females are not distinguished by differences in size or other external features.The adult shell has a slight pitch forward 
In the umbone region. In the young mussels the color is light brown, but this changes to a darker hue with age. An internal feature of the the shell which 18 often present and which is unique among the fresh water mussels of the Missiselppi Valley is a pale orange tint exhibited by the nacre, but since in many cases the nacre is pearly white this is not a universal character of the species. Obviously, the characters enumerated above are not very definite and it is easy at first to confuse Strophitus with other species. With a little experience, hovever, one can soon learn to distinguish It by the conformation of the shell.

All the specimens examined came from the Upper Misalssippi in the region of Falrport Iowa, in which locality it is not a common species,but one rather difflcult to obtain.

\section{METAMORPHOSIS WITHOUT PARASITISM}

The account of the metamorphosis without parasitism given by Leferre and Curtis is of a preliminary nature, and the completion of the study as the authors state (p. 173) was to have been undertaken by M18s Daloy Young,a graduate student at the University of M1ssouri. M1s8 Young, however, did not complete her studies and her notes and figures were turned over to the Department of Zoology.They were placed in the writer's hands for study and verification and in the hope that additional material would enable him to describe the development more completely and to reconclie the conflicting observations of the two published accounte referred to above.

The peculiar form and arrangement of the cord-like conglutinates In which the glochidia of Strophitus are embedded was described by the earlier invest1gators (Lea 1838, Sterki 1898, Ortman 1909), 
but the first observations which showed aberrent development in this species were those of Lefevre and Curtis(1912), who in the course of work upon the mussels of the Upper Mississippl at La Crosse, Nisconsin during the summer of 1908 were unable to secure infections with the glochidia, although repeated attempts were made in which "tine fish were left in small dishes containing many cords for as long a time as 12 hours" (Lefevre and Curtis $112 \mathrm{p}$ 173). This together with the peculiar structure of the marsupium, led these investigators to think that Strophitus might be a species which passed thru its metamorphosis without parasitism. In the autumn of the same year o. single specimen of Strophitus was included in a shipment of mussels to the University of Missouri; and, as the species had previously attracted attention, this specimen was placed in one of the laboratory tanks under favorable conditions and kept under observation. It lived thru the winter and began discharging glochidia February 6 .

The glochidia were imbedded in cords which varied in length from two to ten millimeters and were about one millimeter in diameter. The number of embryos in the larger cords varied from ten to twentyfour. Upon contact with the water the cords became silghtly swollen and a small percentage of the embryos broke thru the egg membrane and the cord to the surface.Part of these remained attached to the cord by the larval thread, which originates at the anterior end of the embryo (F1g. 23) and is fused with the egg membrane at the other end;in other cases, however, the larval thread broke thus releasing the embryos from the cord.It was found that those which remained attached to the cord were st1ll in the glochidial stage while those in which the thread broke and those which semained embedded within the cord were mostly young clams.The young clams possessed a well- 
developed ciliated foot (plate VII) which they used effectively in crawling over the bottom of the dish. After the fourth day of exposure to the water the cords began to disentigrate and at the end of the fifth day both clams and glochidia had died.

Since the majority of the young clams were found within the cords It was thought that the cords might have a nutritive function. But experiments showed that the young clams and glochidia lived longer when they were separated from the cordo. In one instance where a clam was kept for twelve days it had been extruded from the cord immediately after being discharged from the parent. Further evidence was obtained from a chemical analysis by Dr.J.A.Gibson of the University of Missouri, who found that the cords were composed of a chemical substance allied to conchiolin and which could not be utilized as food.

Taken as a whole the facto seem clearly to indicate that metamor-phosis took place within the marsupium and thet the cord does not have a nutritive function.

Miss Young's notes describe the reactions of the glochidia and young clams to various reagents. When treated with various concentrat- Lons of potassium nitrate, ammonium chloride, and sodium chloride the foot of the young clam would contract but no effect was produced upon the adductor muscles.Frog's blood was used with similar results and even etrong hydrochloric acid failed to cause the clam to close. Similar experiments were preformed apon the glochidia of strophitus, which gave reactions very different from those typical for the glochidia of other species. Upon treatment with the above mentioned reagents a minute or more would elapse before the adductor would contract. Then after "winking" a few times they would slowly close, but never did they snap tightly together as other glochidia do. 
From these experiments M18s Young concluded that it would be 1mposs-ible to infect fish with any of the larval otages examined.

Since a large percentage of the embryos which had been extruded were glochidia, and since these would not infect fish it was impor-tant to find out whether they would develop outside the parent. In order to determine this a number of experiments were preformed in which the glochidia were kept under conditions as nearly sterile as posible. Under such conditions the glochidia lived for several days but they did not undergo any change or growth during this time. At the end of three or four days the mantie cells began to diskntigrate after which the embryos soon died.Accordingly it was concluded that these were immature glochidia which had been pre-maturely extruded from the parent.

As a check on the experiments mentioned above Miss Young repeated the experiments in infection already made by Lefevre and Curtis, attempting to infect fish with the young clams and glochidia.Four omall sun-fish were placed in a jar with the glochidia and young clams and the exposure continued for more than an hour without results.Since these fish were readily infected by the glochidia of other clams,it seemed clear that these glochidia had lost their parasitic habit.

Besides these physiological studies Miss Young made a large number of preparations,both whole mounts and sections, illustrating the different stages.These have been studied and figured in the plates,part of the figures being drawn by Miss Young and part of thom by myself.

Since it is important to show that these larvae which were the subject of study by Miss Young and by. Leferre and Curtis as shown 
by their figure 45, poosess the structures characteristic of the stage at which iffe on the bottom is begur ir other species,a series of drawings from whole mounts showing the different stages in metamorphosis is given on plates I, II, and III.Figure I is a drawing of a glochidium in which the metamorphosis is just beginning. Protruding from the anterior end (ant) between the valves is the stump of the larval thread(It). Crowded into a small space at the posterior end (post) are a few darkly staining cells (fc) which may be characterized as the "formative celle" of the embryo, since they produce a large part of the adult body. The remainder of the glochidium consists of a huge central adductor muscle (la Fig.2) covered with the larval mantle (me Figs. 1 and 2 ). Figures 8,9 , and 10 are transverse sections taken thru the stage shown in Figure 1. The section represented by Figure 8 passes thru the glochldium in the plane $a-b$ and shows the beginning of the digest-ive tract (int). Figure 9 passes thru the plane b-c and shows the digestive tract giving off the liver diverticula (1d). Figure 10 pasaes thru the plane c-d, showlng the larval thread gland (It), the aductor muscle (la), and the larval mantle cells (mc).

In Figure 2 the mantle cells have been omitted in order that the adductor muscle (Ia) may be seen. It will be noticed that changes have taken place at the posterior end.The liver diverticulum (Id) is pushing out on either side, and posterior to this is a small protuberence (int) which forms the posterior region of the intestine. And on each side of the intestine is a layer of darkly otaining cells (g) which mark the position of the developing gill buds. Figure 3 is a later stage in which about half of the larval adductor ( $1 a$ ) has been resorbed. The gill buds (g) may be seen on 
each side, the intestire (int) now shows distinctly, and the foot (ft) is assuritre its characteristic shape. Only half the martle cells (mc) are represented in order that the muscle (la) may be shown on one side.A close study of the mantle cello (mo) shows them to have Indistinct outlines and a reduced stalning capacity which is evidence that they are being resorbed.

Figure 4 shows a further reduction in the size of the larval adductor ( $1 a$ ), the remainder of which is taken over to form the anterior adductor (aa) of the adult. The posterior adductor(pa), however, is formed entirely of new tlsoue and may now be seen in the posterior region ventral to the intestine.Other features are the increased length of the intestine (int), the appearance of another pair of gill buds (g), and the addition of a layer of cal-cium carbonate (ns) to the glochidial shell.

F1gure 5 does not show any further development but is interesting because it is still inclosed within the egg membrane (em). Note the orlgin of the larval thread (It) at the anterior end of the embryo and its attachment to the egg membrane.

Figure 6 is the latest stage in development found in Miss Young's material.It is essentially the same as the specimen studied and described by Lefevre and Curtis (Fig. $45 \mathrm{PI}$. XII). It will be noted that in addition to the structures shown above this clam possesses a large liver diverticulum (Id) on each side of the foot. The same stage is represented in anterior view by Figure ?.This stage has been studied further by a series of sectiono (F1gs. 11,12,13, and 14) the planes of which are indicated on Figure 6. Figure 11 is a section taken thru the plane $a-b$. In the center of the figure lies the digestive tract (int) surrounded by the developing pericardiun 
(pc). On the extreme left is a part of the posterior adductor (pa) and between this and the intestine (int) is a spherical mass of cello which later form the vieceral ganglion (vg). Dorsal to these two structures lies the beginning of the kidneys (kd) with its thick glandular cells. On the ventral side the two gill buds $(g)$ protrude into the mantle cavity, which is very large in this plane. Passing anteriorly to the plane $b-c$ the relations change as shown by Figure 12. The gill buds (g) are now represented by two small ciliated patches and the foot ( $f t$ ) now occupies the central part of the mantle cavity. Lying in the dorsal region of the foot (ft) are two small groups of darkly staining cells (pg) which form the pedal ganglia.Dorsal and lateral to these are the otocysts(0). The remaining part of the dorsal region is occupled by the digestive tract (int) which at this point is giving off the two liver diverti-cula (1d). The next section, Figure 13, passes thru the plane c-d and cuts the mouth region. The only points of interest here are a few otrands of the anterior adductor (aa) and a ciliated region. ventral to this which marks the mouth region. It will also be noted that the clam is still inclosed within the egt membrane (em). The last section of the series passes thru the plane d-e at the extreme anterior end and 1 s represented by rigure 14 . The only structures of Interest is a few fibers of the anterior adductor (aa).

Following these 1s a series of figures (PI. VII) drawn from the living specimens. These show a ciliated foot (ft) developed to a stage which is comparable with the foot of any young clam that has just dropped from the fish. The fact that they died at this period 10 no ovidence that the were not fully developed, for it must be remembered that the young clams are always difficult to rear under 
artiflcial conditions.

In nature they are dropped on the river bottom where there is plenty of food both in solution and in the form of unicellular organism. Furthermore the inorganic salts in solution play a very important role, and as the water at the University of Missouri comes from deep wello, it differs very decidedly from river water with respect to this factor. Another difficulty which prevents the keeping of the young clam at this period is the rapid growth of bacteria and protozoa which soon foul the water. Therefore I think it is probable that the artificial conditions of the laboratory caused the young clams to die, and that had river conditions been supplied they would have lived.

From the ebove results, which I have organized and presented from Miss Young's notes, she drew the following conclusions, which are in agreement with the observations recorded by Lefevre and Curtis.

1. The glochidia of Strophitus do not infect fish.

2. The embryos pass thru their metamorphosis within the cords and before the extruaion from the marsupium of the parent clam.

Recently, the problem has been rendered more complicated by the discovery that Strophitus does infect certain fish,Dr.A.D.Howard of the U.S: Blological Station of Fairport Iowa having carried the glochldium thru it metamorphosis on fish, and finding no indication of metamorphosis without parasitiom.

\section{METAMORPHOSIS WITH PARASITISM}

At the ouggection of Dr. Curtis I took up the investigation of this problem and have made observations covering a period of two years.Part of the work was done at the U.S.Blological Station 
of Fairport Iowa, and part of it was done at the Zoological Labor-atory of the University of Missouri.

One of the first problems which I had to solve was the collection of material. Strophitue is not orly restricted in ito distribution, but is also very thinly scattered over the bottom in the region where it is found. One may drag the "crow foot" or use the"shoulder rake" for a whole day on one of these beds and only get two or three Strophitur. For this reason it was necessary to rely entirely on the "Clammers" for the collection of the material. By making arrangements with several of these nen I wo able to secure all of their Strophitus and in this manner obtained sufficient material for my observations.

When the mussels were brought into the laboratory they were care-fully pried open to ascertain whether or not they were gravid, and all such individuals were isolated and kept under observation. In most cases the gravid specimens died soon after being taken from the river. When placed in the water they would crawl about in the sand for a time, then begin discharging cords and in most cases die before the gills had been emptied of their glochidia. Those which were not gravid, however, readily adjusted themselves to laboratory conditions and lived into the next breeding seasor.

Since the center of interest in the investigation of this iffe history lies in the demonstration of the presence or absence of parasitism,most of the work was confined to the development follow-ing the glochidial stage. The plan of study was to ascertain the stage of development at the time the cords were discharged,determine whether the embryos developed any farther after their discharge from the parent, and to verify Howard's experiments by new infections.

In the above study and throughout the work whenever it seemed 
necessary fixed and stained material has been examined in section or in whole mounts. In order to kill the glochidia expanded it is necessary to treat them with a narcotizing substance, aince treat-ment with any fixitive caused them to close.Even hot corrosive sublimate falled to kill them quickly enough. But when hydrochlorate of cocain was olowly added to the water for a period of one or two hours they could be placed in the fixing solution without any contraction of the adductor.

A.Observations on Strophitus toward the close of the breeding season.

The Unionidae may be divided into two groups, the "stumer breeders and the "winter breedez". In the former case the period of gravidity extends over the oummer months, while in the latter case ovulation takes place in August and the females carry ripe glochidia from october to the early oummer.As Strophitus is one of the winter breeder, I was able to collect at Fairport, during the summer of 1914, materlal representing that part of the breeding season which is completed in the early oummer, and also materiel which enabled me to follow the development in the early part of the next breeding season. Collecting was begun the first of July on which date I obtained four gravid Strophitus taken with the "crow foot". When some of the cords were removed and placed in water they behaved as had been described,becoming slightly swollen.The glochidia, however, behaved differently. Instead of lying inactive these glochidia kept up a continuous "winking" and within a short time most of them had broken thru both the egg membranes and the cords, quite a number of them remainling attached to the cord by means of their larval 
threado. All the embryos were examined carefilly to ascertain the stage of development and in all cases they were found to be typical glochidia, there being not the slightest indication of metamorphosis. The glochidia were then set aside in dishes in which the water was changed often in order to keep down the growth of microorganisms and to ingure plenty of oxygen;but in spite of these precautions the larvae died within a few days without showing any signs of metarorphosio.This was repeated on several occasions at Fairport during the suminer and also at Columbia in the fall of 1914 and in both the fall and spring of the years 1915 and 1916 . In none of these experiments was there any growth after the glochidia had been discharged from the parent. Since Miss Young's notes and those made by Lefevre and Curtis at La Crosee in June 1908 record the same results, and oince in $m_{y}$ experiments at fairport there was a very close approximation to river conditions, I think we may conclude that the glochidia of strophitus do not develope after they have been discharged from the parent.

The next supply of gravid Strophitus was collected on July 13. In addition to performing the experiments described above I endevored to infect a "crappie" (Pomoxis sparoides) with these glochidia and was successful. The fish was placed in a small jar which contained glochidia and in a short time a number of them had become attached to the gilis where they produced hypertrophy of the tisoues and became encysted in the normal manner.As this was the last gravid specimen obtained from the 1913-14 breeding season, further infection experiments at Fairport were impossible. 
B. Observations on Strophitus at the beginning of the breeding season.

Between July 13 and August 7 eighty-five Strophitus were collec-ted but none of these was gravid. They were put into a large tank thru which flowed filtered river water and were closely watched for the beginning of the 1914-15 breeding season. Toward the latter part of July I noticed that in some of the specimens the dorsal region of the foot had become swollen and found that it was crused by the rapidly developing gonads. On August 3 one of the males was observed discharging spermatozoa. The amount of discharge was extremely large; for the aquarium which was about $3 \times 2 \times 1 \frac{1}{2} \mathrm{ft}$. was rendered milky within a short time.The particles which were being discharged looked too large for spermatozoa, and upon examination it was found that each particle consisted of hundreds of spermatozoa arranged in a hollow sphere with the heads pointing inward. (Fig.2I). Upon contact with the water the spheres disentigrated,presumably ga a result of some change in the chemical environment and the mechanical effect of the vibrating tall. A few days later the same mussel discharged spermatozoa again in equal numbers.This gives some idea of the number of spermatozoa that must be produced when fertilization is effected by such a haphazard process.

On Aug.8, the day following the last discharge of spermatozoa, I found a gravid female in one of the aquaria.Ovulation must have taken place only a day or two earlier because the embryos had developed wo farther than the blastula stage. Figure 22 is a cross-ection taken thru the outer gill of this specimen. It will be noted that the embryos (emb) fill the central part of the old water-tubes and that the superficial water-tubes have been formed. 
These are made by the outgrowth and fugion of a vertical sheet of tisoue which cuts off the outer sides of the old water-tubes. In the gravid gill, the resplratory current passes thru the ostia into these superficial water-tubes, which run up either side of the marsuplum, then into the suprabranchial chamber;oxygen being furnish-ed direct to the imbryos by diffusion. Another feature to be noted is the conglutinating substance (con) which surrounds the embryos. Th1s will later form the cords and is probably secreted by the walls of the water-tubes.

After Aug.8 a large percentage of tine females collected had ovulated.During the month of August the collections were as follows. Aug.II -... 6 Etrophitus collected l gravid.

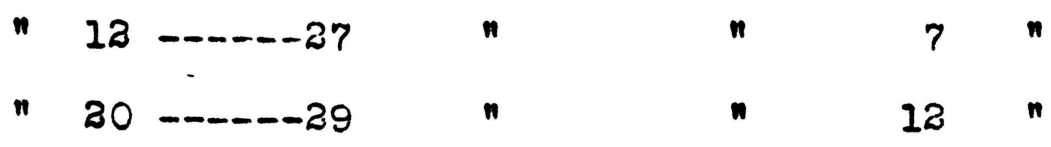

By the end of August the development of the larvae within the gravid females had reached a stage in which the glochidial shell was formed and the embryo was just ready to begin the invagination which forms the glochidium.

The next collections were made in october and the mussels were shipped to Columbia Missouri. When placed in the water they extruded rtpe glochidia but contained no stages in metamorphosis, nor did any further development take place after they had been discharged from the parent. (F1go. 23 and 24 ).

After determining the stage of development the next step was to see if the glochidia would infect flsh. Two cat-fish,two large ounperch, and a number of small crappies were used in the experiment. In the case of the sun-perch and the cat-figh negative seoults were obtalned;but in the case of the crappie the glochidia became encysted and passed thru their metamorphosis. (Figs. 25 to 29 inclusive). 
At the end of twelve days the young claris vere found crawling over the bottom of the dish. Atudy of the figures referred to above and of the sections (PIates XII, XIII; and XIV) shows them to possess all the structures of the juvenile at this period.

\section{CONCLUSIONS}

These results confirm those of Howard at Falrport and establish without doubt the parasitic habit of Stroph1tue. From the number of experiments that have been performed I think we way safely conclude that this is the usual method of development in this species. The reason M1ss Young and Lefevre and Curtis did not get infections was due to the selection of the wrong kind of fioh. At the time the first experiments were perfor ned it was not known that there was a specificity in the parasitism. The work of Lefevre and Curtis did show that some species of fish were wore susceptable than others to certain glochidia, but no further analysio was atte moted. Howard in his work at Falrport concelved the ldea that there might be different hosts for different species of mussels, and accordingly made an extended study of natural infections in the river. This in connection with some experimental work showed,comparable with. that which so cornwonly occurs in other parasitic forms, specific hosts for certain of the mussela. It was found for example that the "gar" $($ Lepisosteus platostomus) was the natural host of Lampail1s anodontoides, and that the "channel cat" (Ictalurus punctatus) as the natural host of quadrula pustolosa. This makes clear the neg-ative results of Lefovre and Curtis and those of Miss Young. In the latter case it will be noted that the sun-perch was. used which 18 evidently not one of the natural hosts of Strophitug. 
Therefore, the resulto only indicate a restriction in the parasitis and do not show that Strophitue has lost its parasitic habit.

In regard to metamorphosis without parasitiam there can be no doubt as to the facts as shown by Figure 45 in Leforre and Curtis and confirmed by the notes of Miss Young. Not one but many specimens were observed,as the: were extruded during a period of almost eight weeks, and the material and flgures show clearly the adult structures of the mussel. But the fact that I have examined fifty or more females containing ripe glochidia with no indications of metamorphosis shows that these conditions are of rare occurrence. Upon a consideration of the observational and experimental data from all sources I think we way conclude: first, that the glochidia of Strophitus usually pass thru their metamorphosis on certain fishes;second, in a single case where the mussel was kept in the laboratory, they were observed to undergo metamorphosis without paras1tism.

The above facts suggest the following question. Is this a form Which lo just beginning to change its habits from a paraittic to a non-parasitic existence? The case is not without a parallel In the Unionidae. Howard has discovered that Anodonta imbecilis completes 1ts development without parasit1sm, metamorphosis taking place within the marguplum in the absence of any conglutinate substance such as the cords of Strophitus. Experiments with the glochidia failed to give infections on fish. The glochidia closed their valves upon the fins or gills of the fish and remalied attached, but within a few days they dropued off without under-going any change. Howard's paper does not state how many fish twere tried, and this may also be a case of restricted paras- 
-itisw. But leaving this cut of account it would seem that Anodonta lmbecillis which is a heriaphroditic species and is not closely related to Strophitus is abandoning its parasitic habit. The life cycle is being telescoped so that the whole development takes place within the parent. Th1s way also be the airection in which Strophitus is moving. Assuming that it 1s, we have here a case of convergent evolution, and these two cases wight be the first of a wide serles of changes marking the the general evolutionary trend in the whole group.

Anotier possiole explanation of the conflicting data is that sowe chemical substance present in the water was responsible for the netamorphosis without parasitian. Since the clan does not grow to any appreclable ${ }_{\Lambda}$ ithile on the fioh, and since the larval atructures are resorbed during metamorphosis, it may be that the relation between floh and glochidium is more a matter of stimulation than of nutrition, it may be that the tissues of the fiah produce sore substance which initiates the matanorphosis. If such a substance had been present in the acuarium where the oingle specinen frcm which glochidia and young mussels were obtained at Columbia in the Winter of 1909 it wight have reached the -mbryos by diffusion thru the walls of the marsupium and thus caused the development which was recorded. 
7. BIBLINGRAPHY

Herbers, Rarl 1913 Entivicklungagechichte von Anodonta cellensis Schrot. Ze1tsch. f. Wiss. Zoologie, Bd.108.

Howard, Arthur Day 1914 A Second Case of Metamorphosis without Parasitiom in the Vnionidae. Science Vol.XL No.102?.

Some Cases of Narrowly Restricted Parasitiom among Comaralal Species of Fresh Titer Musselo. Trana. Am. Fish. Soc.

Lefevre, Goorge and Curt1s, Winterton C. 1910 Studies in the Reproduction and Artiflcial propagation of Fresh Tater Mussela. Bull. bereau of fisheries Vol. XYX Lea, Isaac 1838 Observations on the genus Unio together with descriptions of new genera and species..Pa. (Origin-ally printed in transactions of American Philosophical Soclety and Journal Academy of Sciences, Pa.)

Ortman, A.E. 1909 The breeding season of the Unionidae in Pennyzlvania. Nautilua, vol, 22, p, 91-95 and 99-103. Sterk1, V. 1898 Some observations on the genital organs of the Unionidae etc. Ib1d., vol.12,p. 18-21 and 28-32. 


\section{KEY TO ABRREVIATIONS IN PTATES}

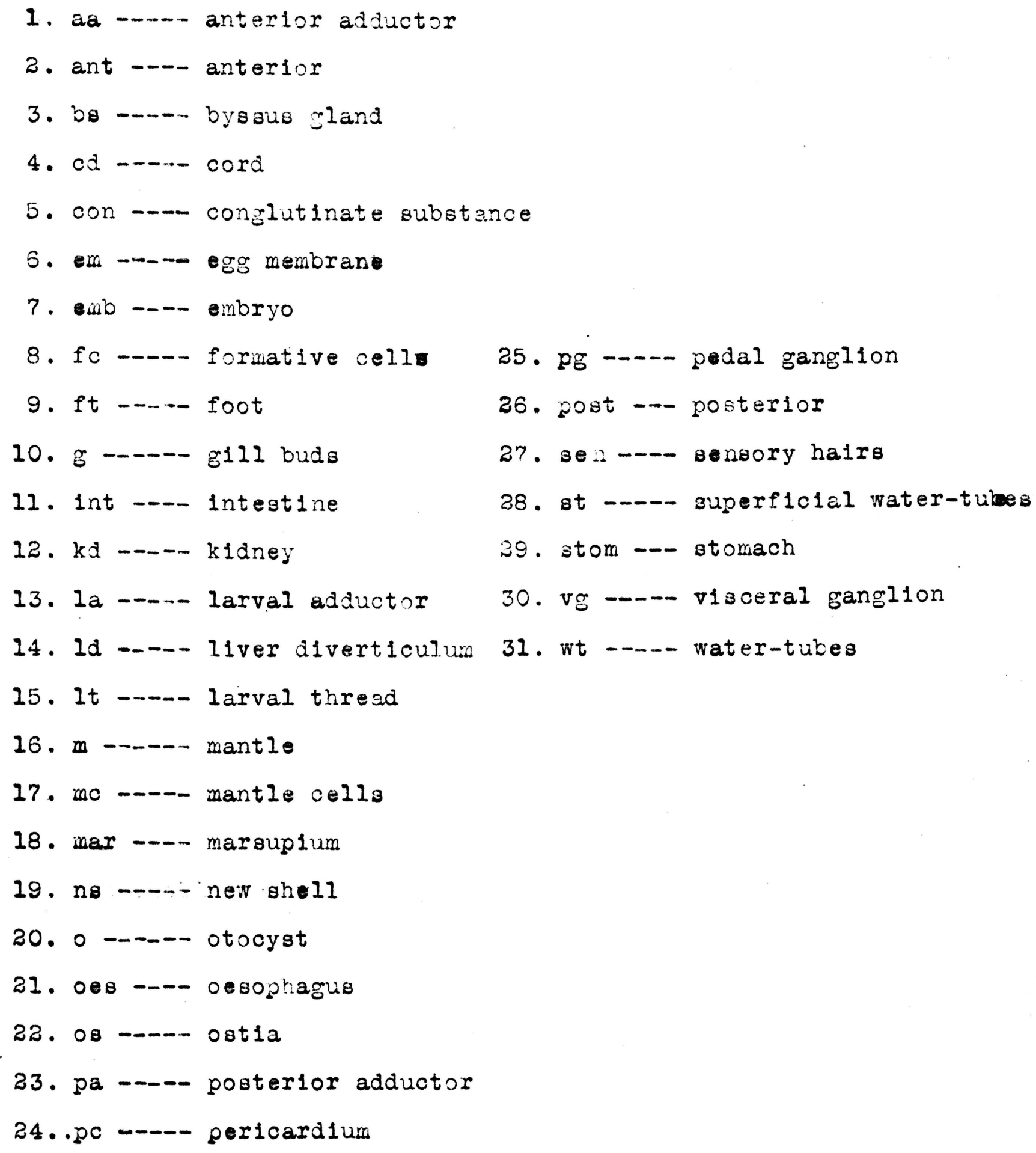


Figures 1 to 7 inclusive (Plates 1,11, and 111.) are drawn from whole mounts of Strophitus embryos and 11lustrate motamorphosis without parasition. Camera luclda, Le1tz oc.4 obj.16.

\section{PLATE I}

Figure i. Glochidium of Stroph1tus edentulus ventral view, anterior end (ant) above. Showing the large cells of the larval mantle ( $m c$ ), the larval thread ( $1 t$ ), the beginning of the intestine (int), and the formative cells (fc) which later give rise to the ad-ult organs. The lines $a-b, b-c, c-d$ indicate the planes of sections represented by figures 8,0 , and 10 .

Figure 2. Orientation sace as above. In this figure the micros-cope was focused at a lower level in order to show the larval adductor ( $1 \mathrm{a}$ ). It represents a stage in development just following that shown by figure 1. Note that the formative cells (fc) hav assumed a definfte arrangement which marks the liver diverticulum (1d) and the beginnings of the intestine (1nt). Lying on elther side and lateral to the intestine is a row of rapidly dividifg cel1s (g) which are the rudiments of the gi11s.

Figure 3. Orientation as above. At the anterior end the larval mantle cello (mc) are represented on the right side while on the left side the larval adductor (la) is shown at a lower focus. It $w 111$ be noted that about half of the larval adductor has been resorbed, the foot (ft) has assumed its characteristic shape, the intestine (1nt) now shows plalnly, and near the posterior end on 
each side are seen the gill buds $(g)$.

\section{PLATE II}

Figure 4. Young clam drawn from ventral view Nith valves olightly flexed. The larval adductor shows a further decrease in size and may now be calles the anterior adductor (aa) of the young clam. Other changes are the increased length of the intestine (Int) shown by the developing fold, the four gill buds $(g)$ in place of two, and the posterior adductor muacle (pa) which has been formed ven-tral to the intestine (int). It will also be noted that a thin layer of calcium carbo nate ( $\mathrm{n} s$ ) has been added to the glochidial shell.

Figure 5. Youngclam st11l inclosed within the egg membrane (em). The larval thread (It) originates at the anterior end of the embryo and becomes attached to the egg membrane (em) in that region. Other structures are similar to figure four.

Figure 6. This represents the latest stage of developwent reached by bthe specimens obtained by Miss Young in the absence of infection. The flgure shows the anterior adductor (aa), the foot ( $f t$ ), the liver diverticula (Id), the intestine (int), and the g1Il buds $(g)$. The IInes $a-b, b-c, c-d$, and $d-e$ mark the plane of sections represented by figures 11,$12 ; 13$, and 14 .

\section{PLATE III}

Figure 7. Anterior view of stage similar to that shown in Figure 6. Note the well developed clliated foot.

Figure 8. Cross section thru plane $a-b$ of stage represented by by figure 1. Showing intestine (Int), the visceral ganglion (vg), and the 
and the larval mantle cells (mo).

Canera, Le1tz oc.z obj.7.

\section{- PLATE IV}

Figure 9. Thru plane b-c of stage represented by rigure 1 . Showlng the digestive tract giving off the liver diverticula (1d), a group of formative cells ( $f C$ ), and the cells of the larval mantle (xac). Camera, Leitiz oca obj.r.

Figure 10. Thru plane c-d of stage represented by Figure 1. Showing the larval thread gland (1t), the larval adductor (1a), and the larval wantle cells (mc). Camera, Leitz Oc.2 Obj.?.

\section{PLATE V}

Figure 11. Cross-section of young clam represented by Figure 6 . Passing thru posterior end,plane warked by line $a-b$. The tube in the center is the intestine (int). Proceeding laterally on the left side the following otructures appear in order; visceral ganglion ( $\mathrm{vg}$ ), kldney ( $\mathrm{kd}$ ), posterior adductor (pa), and g1ll buds $(\mathrm{g})$.

Figure 12. Section anterior to Figure. 11, thru plane b-c. Showing the digestive tract giving offthe liver diverticula (1d), the pedal ganglia (pg), and the clliated foot (ft).

\section{PLATE VI}

Figure 13. Cross-section thru plane c-d Figure 6 . Note that the clam was still inclosed within the egg membrane (ew). The anterior adductor (aa) is shown.

Figure 14. Cross-section thru extrewe anterior end,plane d-e, Figure 6. The remains of the larval thread gland ( $1 t$ ) and the anterlor adductor muscle (aa) are shown. 
Figures 15 to 20 includve are arawings from living Stroph1tus that had passed thru their retarorphosis without parasitism and were woving about upon the bottom. Note the well developed ciliated foot (ft) and the protruaing wantle which is characteristic of the young class in this stage of development. Camera, Leitz oc.2 0j.3.

\section{PLATE VIII}

Figure 21. Section thru a packet of Strophitus spermatozoa.

Figure 22. Cross-zection thru the outer gill of a gravid Strophitus a few days after ovulation. The superficial water-tubes (st) have been formed thus inclosing the embryos in the central part of the 0ld water-tubes (wt). The embryos are in the blastula otage and are surrounded by a conglutinate substance (con) which later forms the cords.

\section{PLATE IX}

Figure 23. Side view of glochidium just extruded from the cord showing sensory cells (sen), larval mantle cells (ma), larval thread (1t), egg membrane (em), and cord (cd).

Figure 24. Glochidium with larval thread (It) and everted egg membrane (em) attached. 
Figures 25 to 29 inclusive (Plates $X$ and $X I$ ) are drawn from living specimens that had passed their metamorphosis on a fish (Pomoxis sparoides) and were actively crawling over the bottom.

Camera, Leitz Oc.4 Obj.16.

PLATE $X$

Figure 25. Side view of a young clam showing how the mantle $(\mathrm{m})$ extends beyond the glochidial shell.

Figure 26. Dorsal view of young clam expanded, showing the c1llated foot.

Figure 27. Ventral view of young clam showing mantle $(m)$, anterior adductor (aa), posterior adductor (pa), gills (g), and foot (ft).

\section{PLATE XI}

Figure 28. Drawn from contracted specimen, ventral and side view.

Figure 29. Same view as Figure 28 except clam 1s expanded. Showing anterior adductor (aa), posterior adductor (pa), the foot ( $f t$ ), the bysous indentation (bs), the gill buds ( $g$ ), and the mantle $(m)$.

The figures in plates XII;XIII, and XIV are drawn from a series of sections of the stage represented by the previous drawings (F1ga. 25 to 29 inclusive). Leitz projection apparatus, 0c.4 Obj.4.

\section{PLATE XII}

Figure 30. Taken thru extreme posterior end showing the Intestine (int) and the posterior adductor (pa).

Figure 31. Anterior to Figure 30. Showing intestine (int), posterior region of the foot ( $f t)$, sections of gill buds $(g)$, 
and the adult mantle cells $(x)$.

Figure 32. Section thru region where intestine (int) bends down into the foot (ft).

\section{PLATE XIII}

Figure 33. Section showing intestine (int) in the ventral region of the foot (ft). Also shows inner and outer epithelium of the mantle $(m)$, and sections of the gill buds $(g)$.

Figure 34. Section taken thru the central region of the foot (ft). Showing stomach (stor) occupying most of foot,a fold of intestine (int) ventral to stomach,a section of the kidneys (kd) in dorsal and lateral region, and sections of g1ll buds (g).

Figure 35. Section passing thru anterior region of the foot. Showing oesophagus (oes), and kidney (kd).

\section{PLATE XIV}

Figure 36. Section thru extreme anterior end showing anterior adductor (aa), and the anterior tip of the foot ( $f t$ ). Space between dorsal part of foot and anterior adductor marks the position of the mouth. 


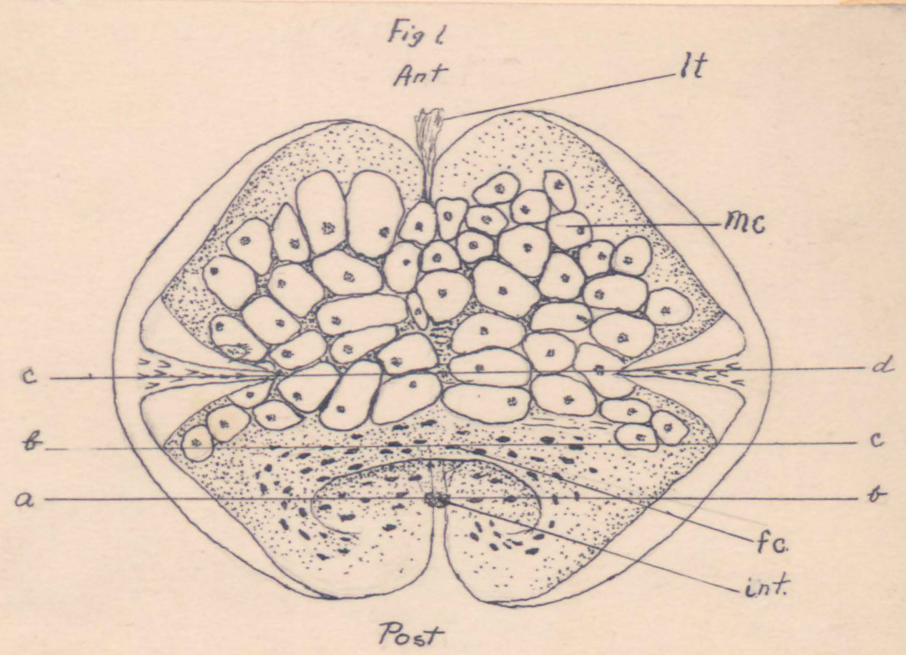

Fig 2.
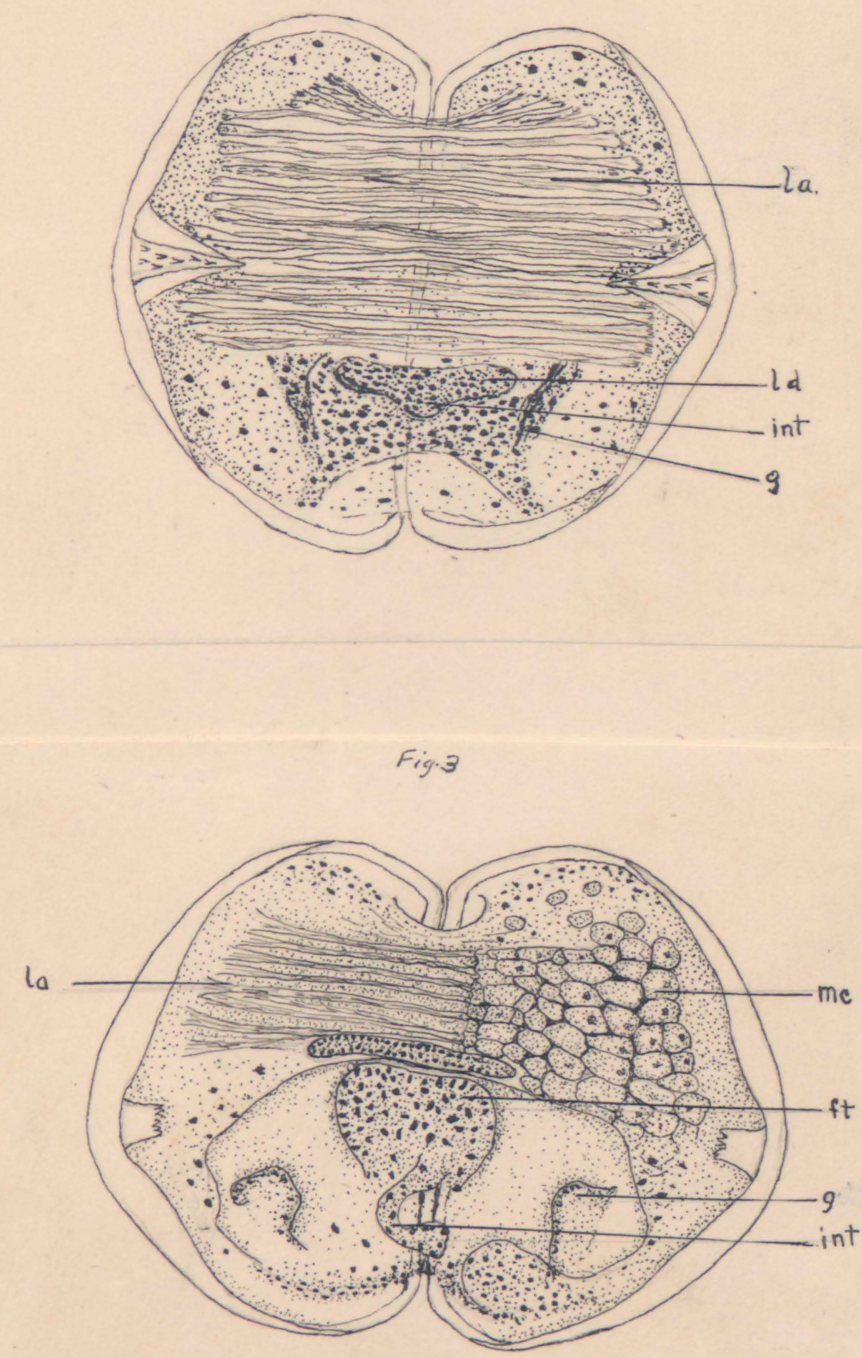


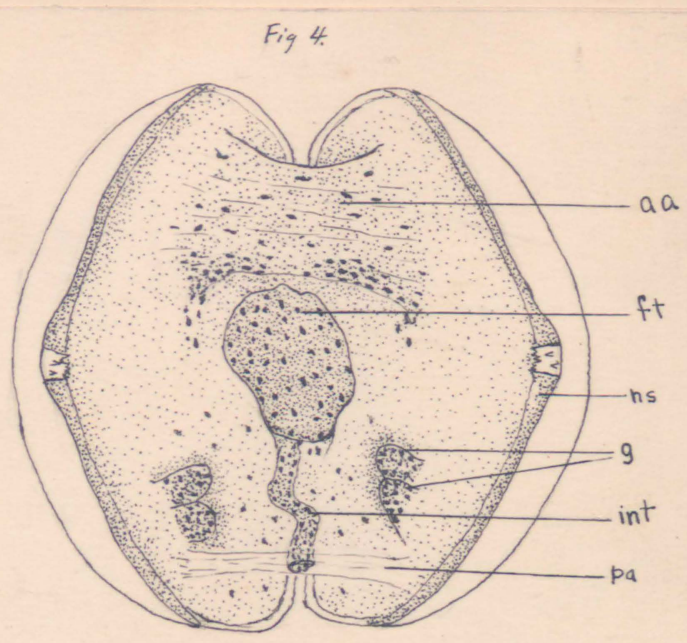

Figs

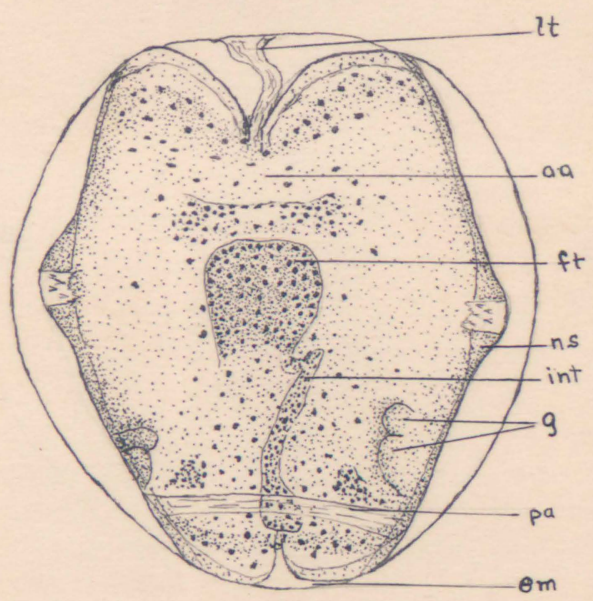

322

Fig 6

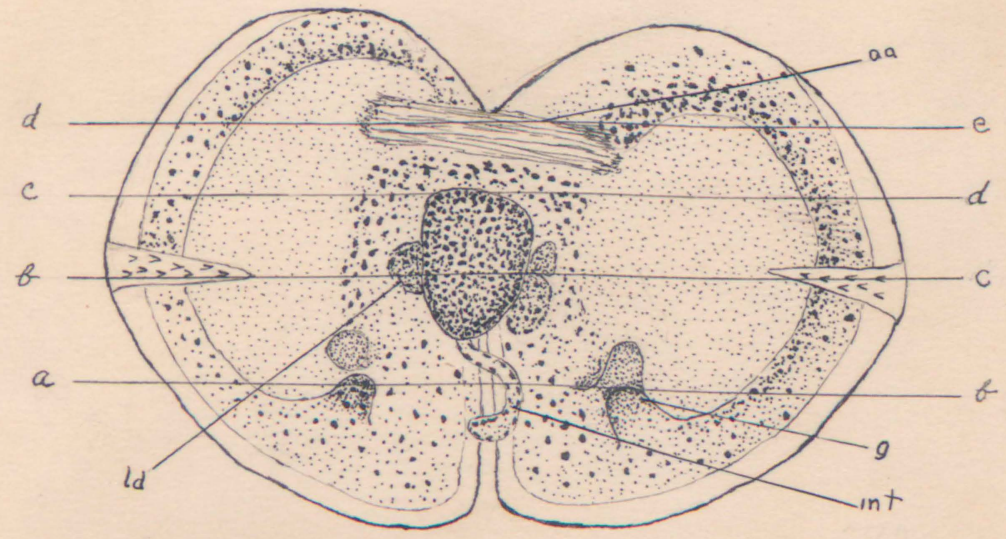




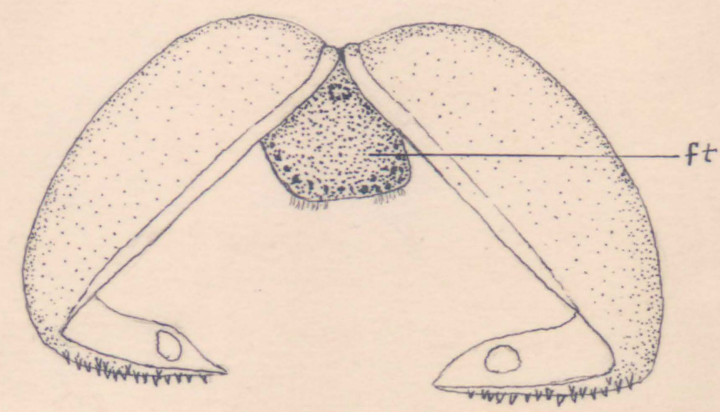

Drawn by EiA,Martin

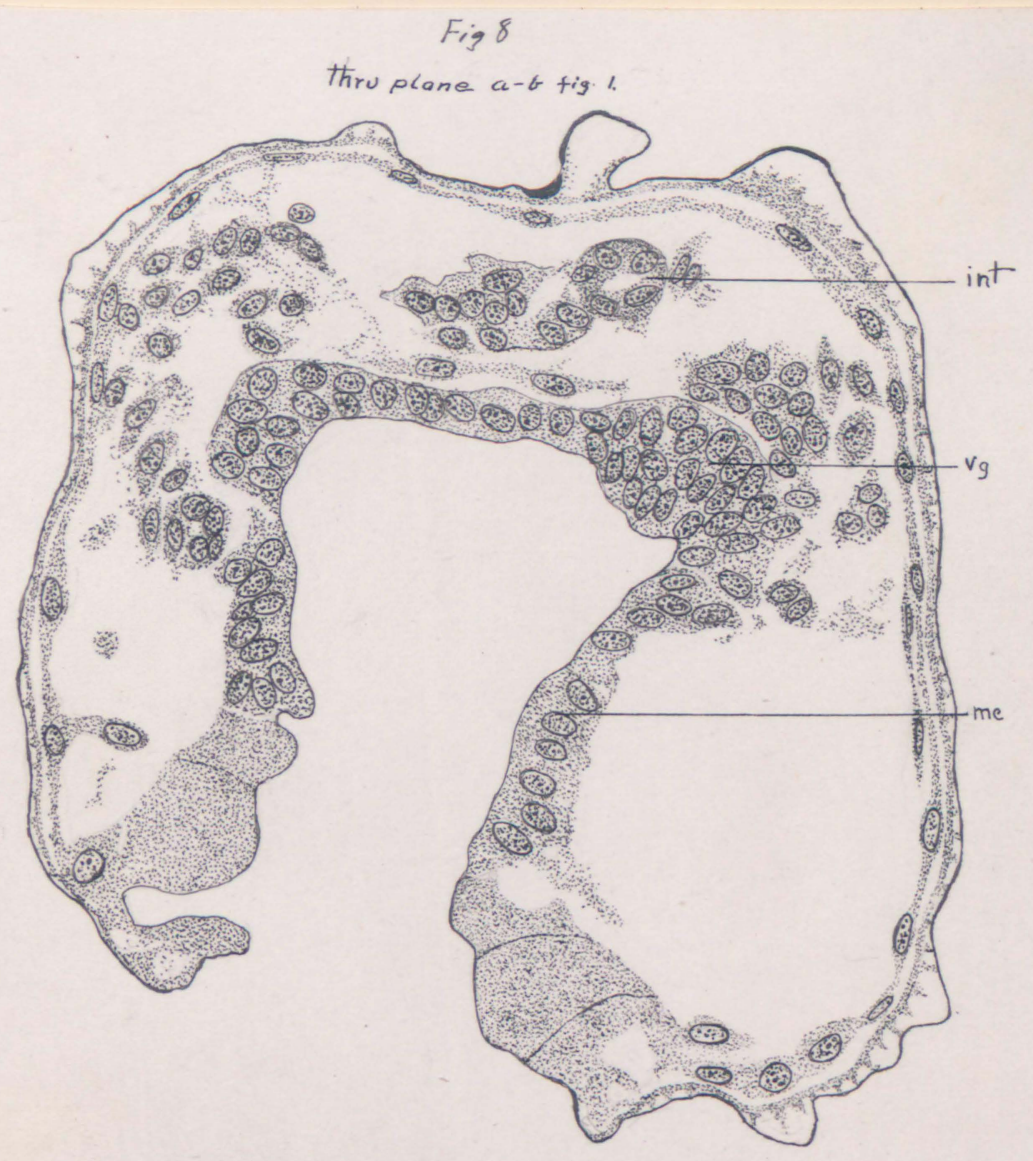




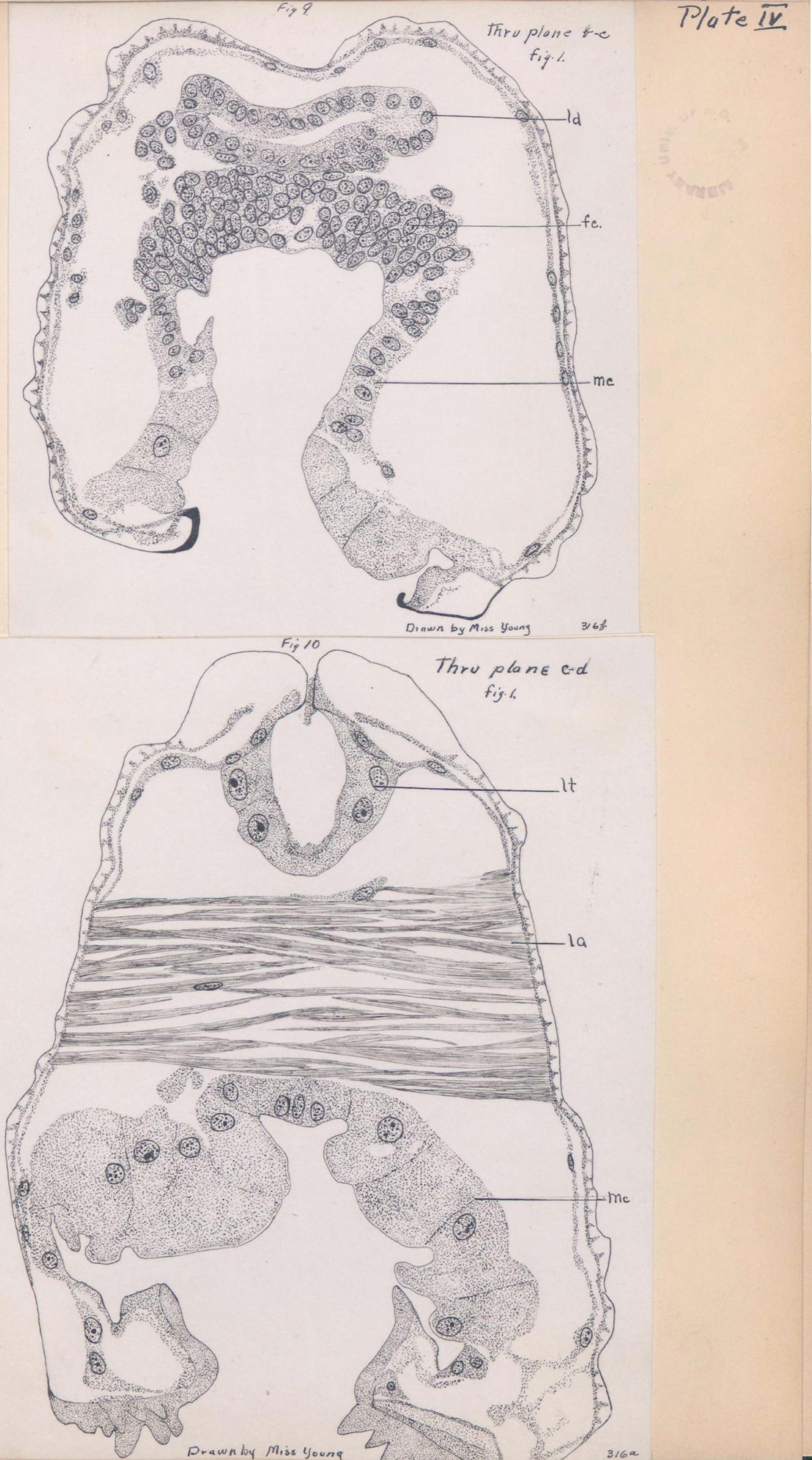


Thro plane $a-b$ fig 6

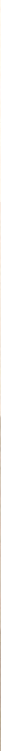

Fig 12

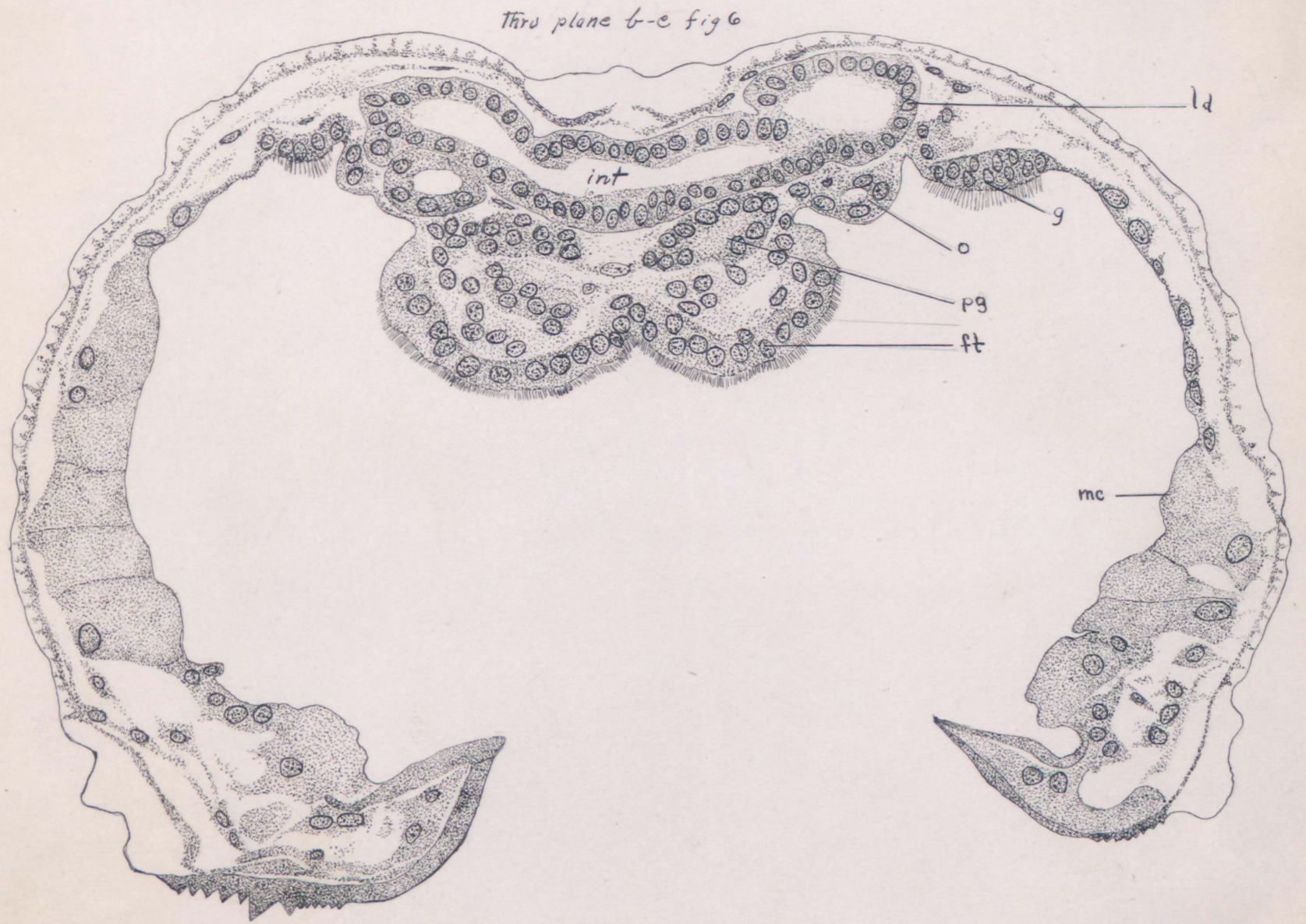






Drown by Miss young

$3 / 46$

Fig 14



Drawn by Miss young $3 / 6 a$ 




Fig 16

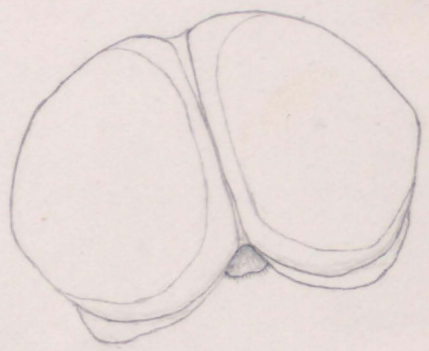

Fig 17

Fig 18
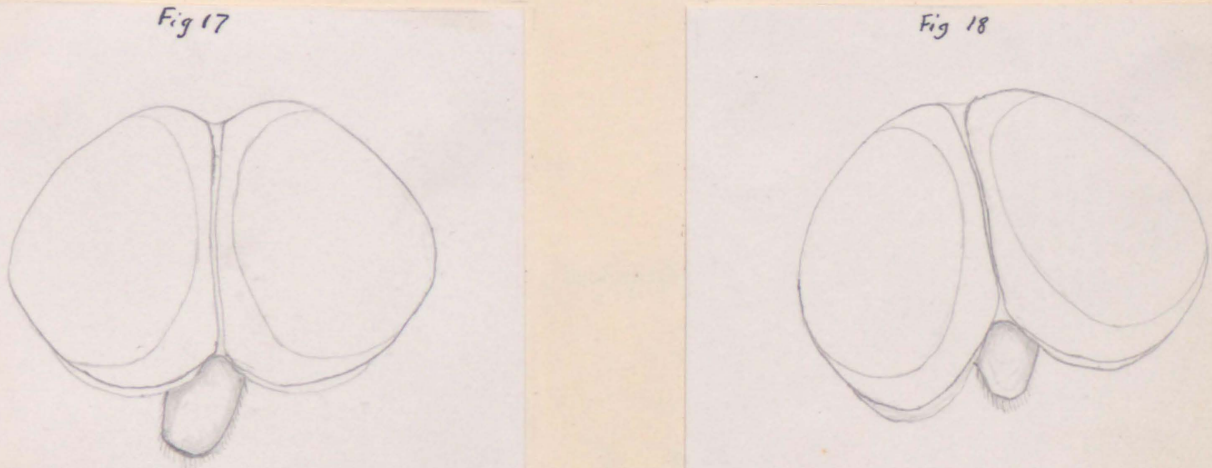

Fig 19

Fig 20
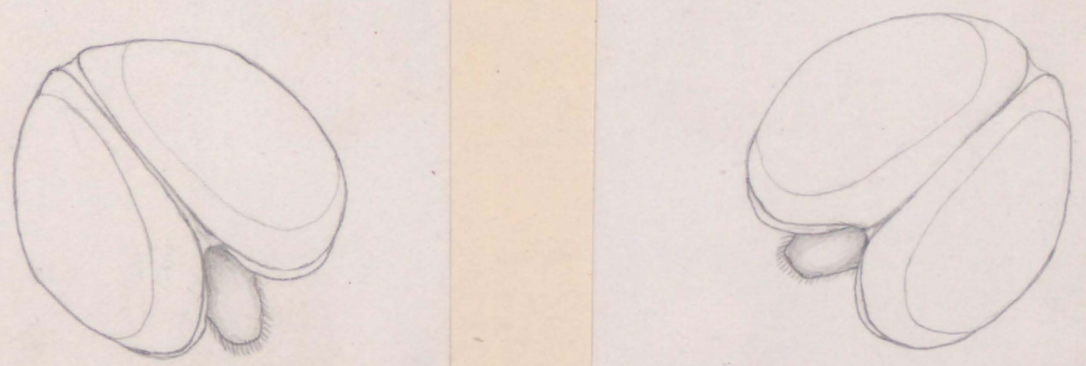

Drawn by Miss Young. 
Fig. 21.
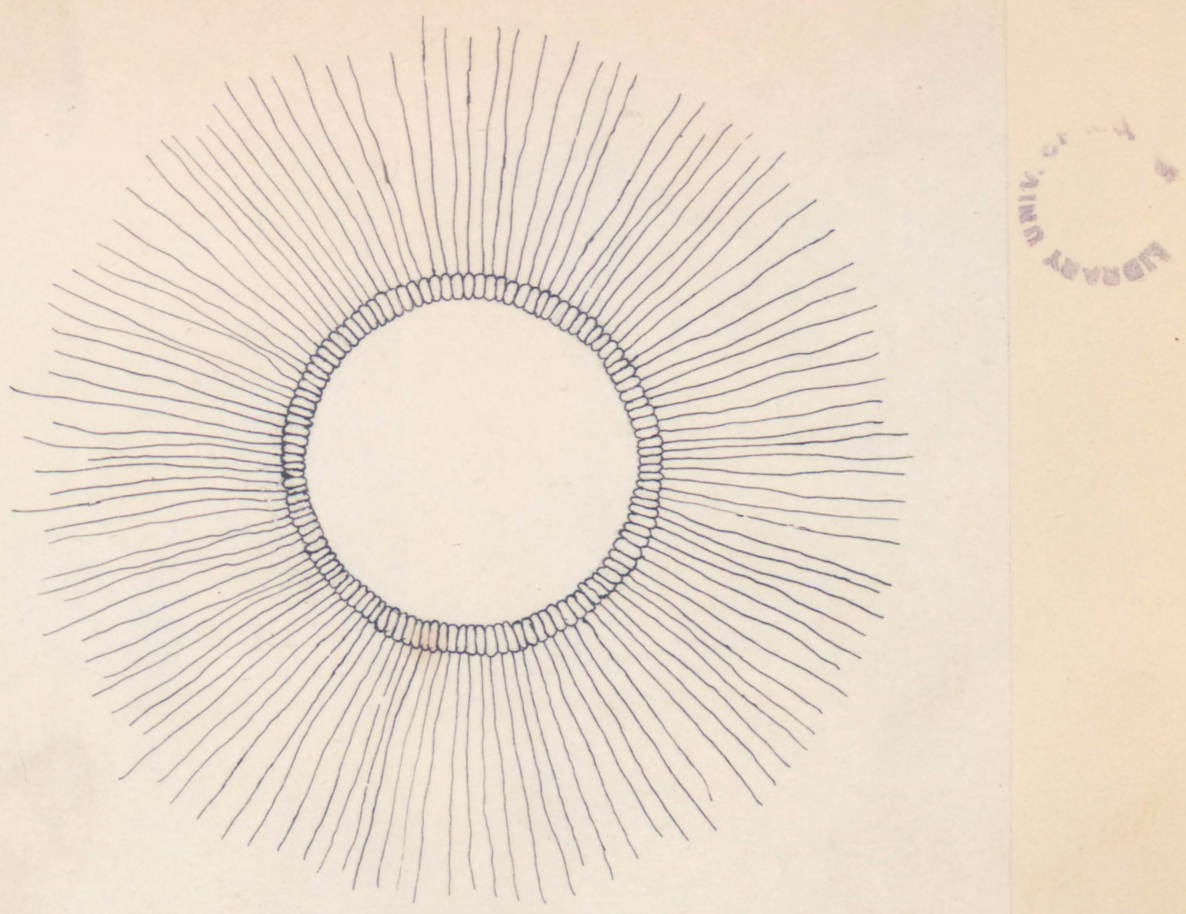

$F_{i g} z_{2}$

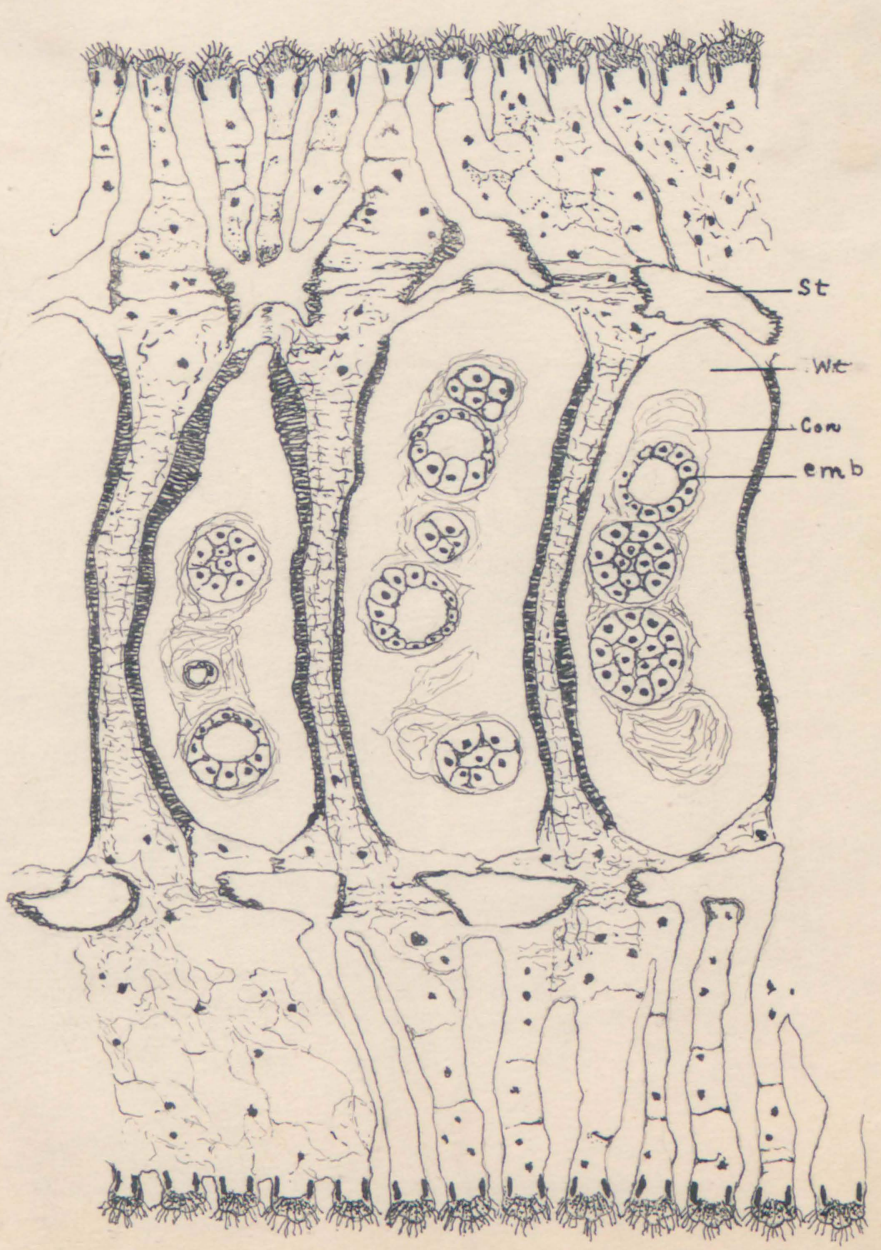




$$
\text { Fig } 23
$$

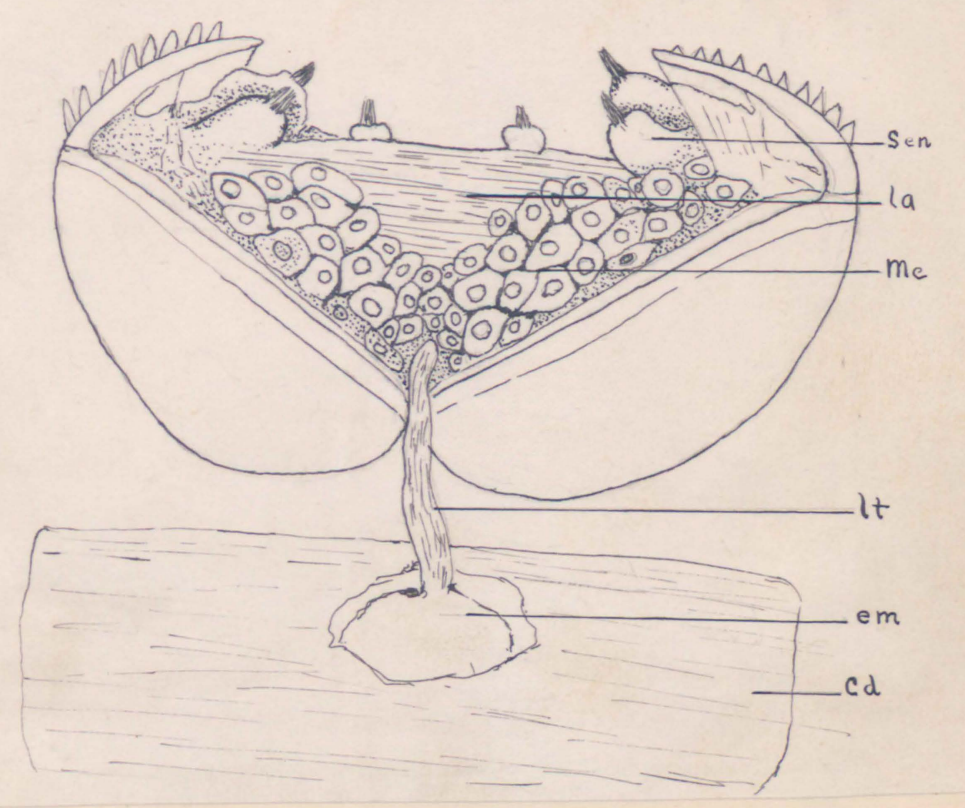

Fig 24

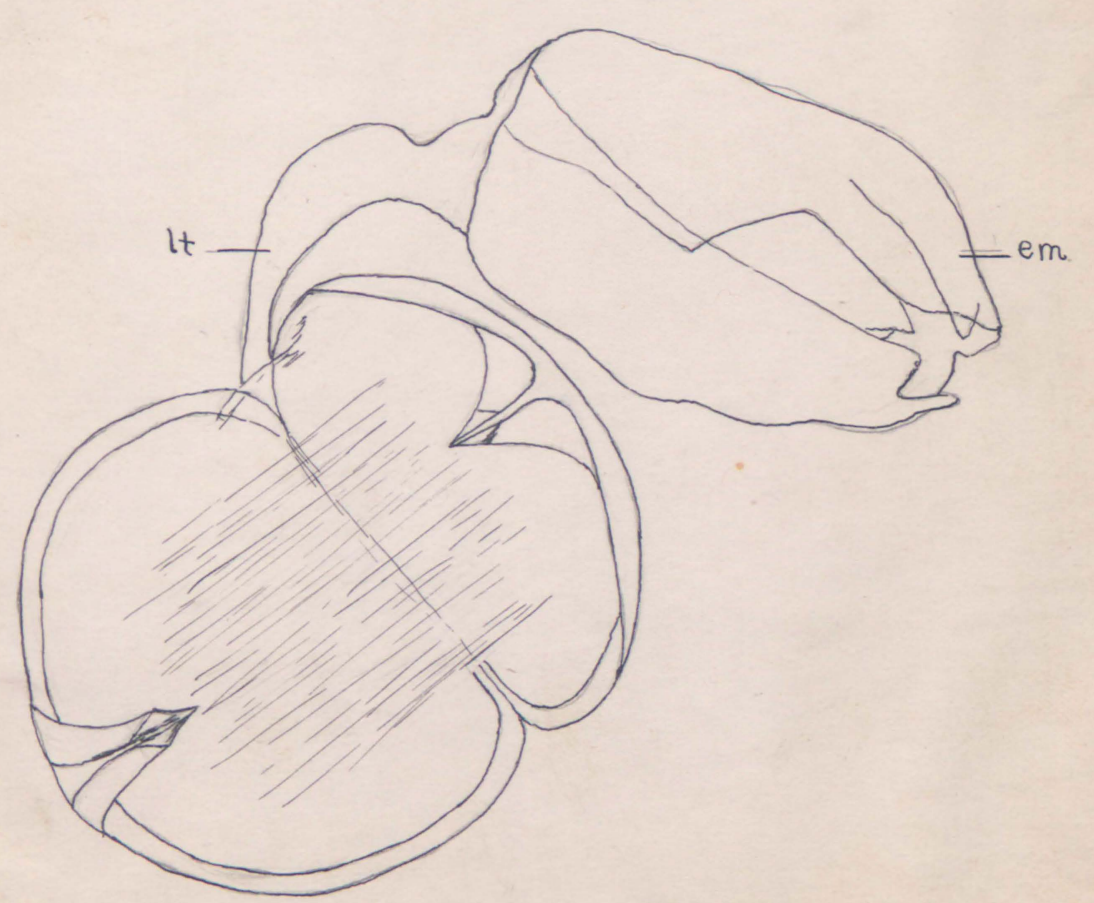


Fig. 25



Fig 26



Fig. 2 ?

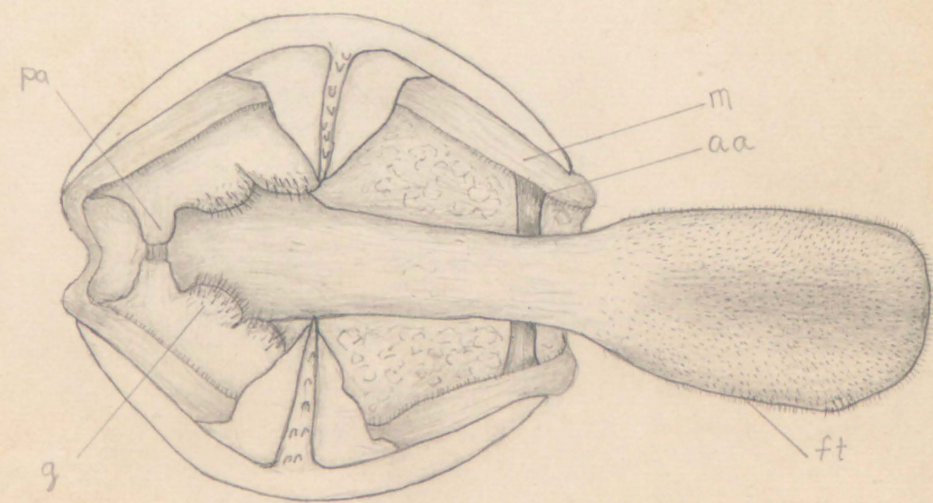


Fig 28
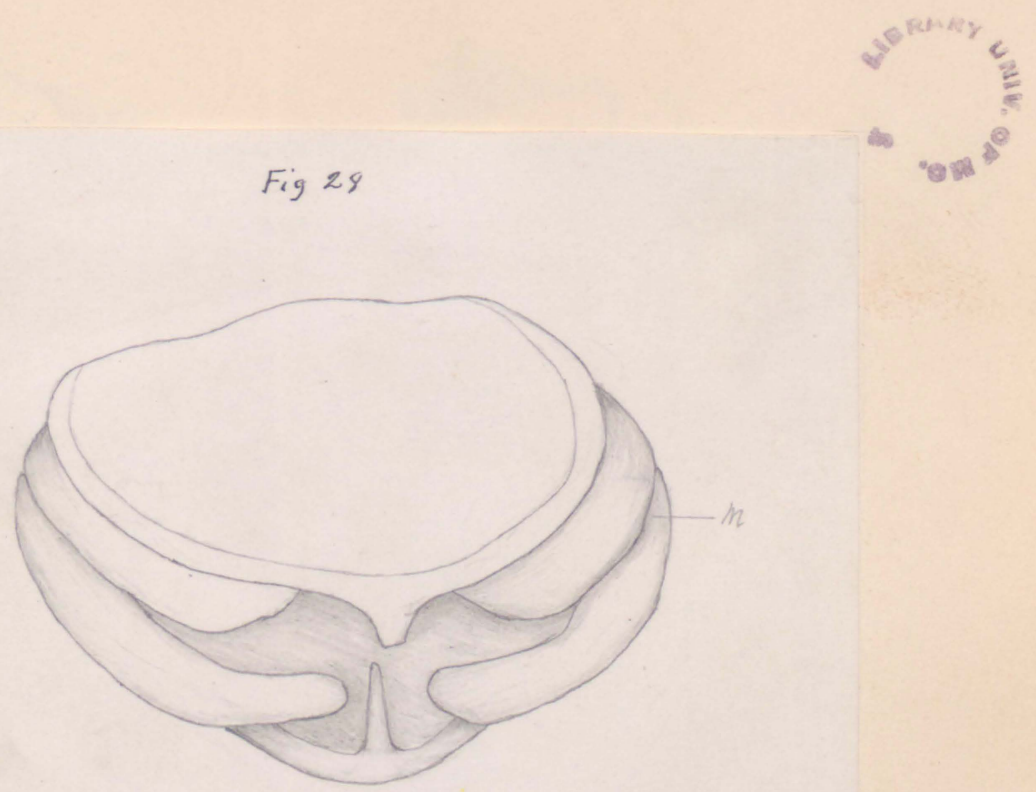

Fig 29

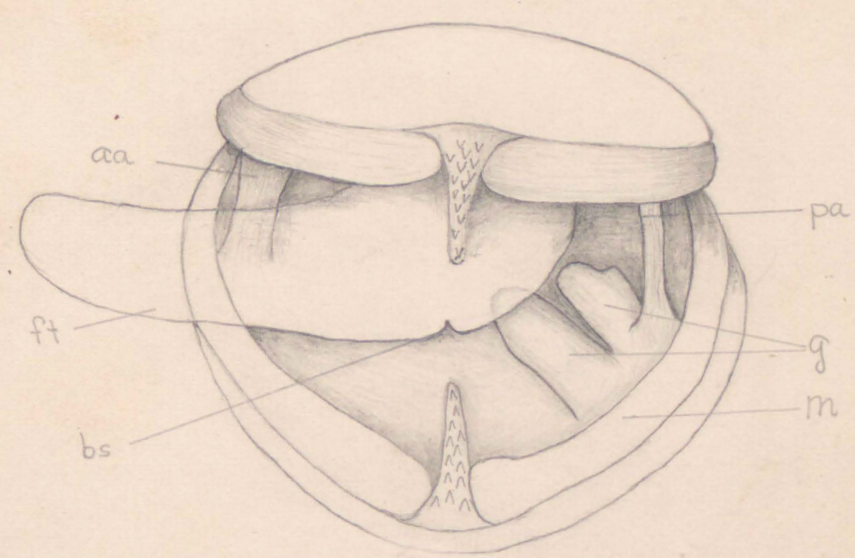


Fig 30

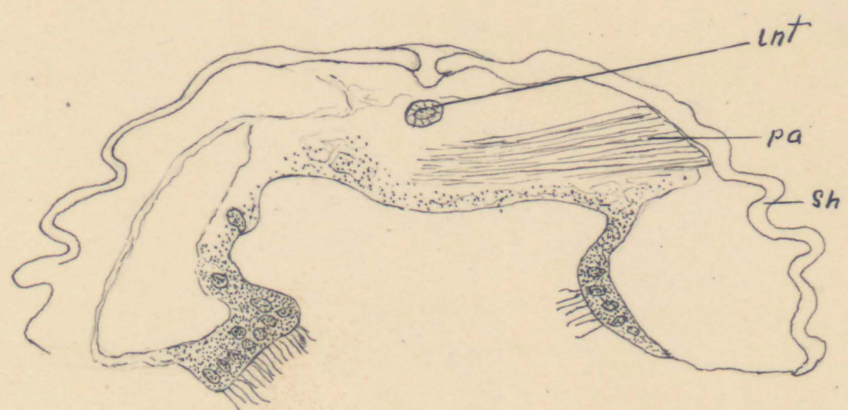

है

Fig 31

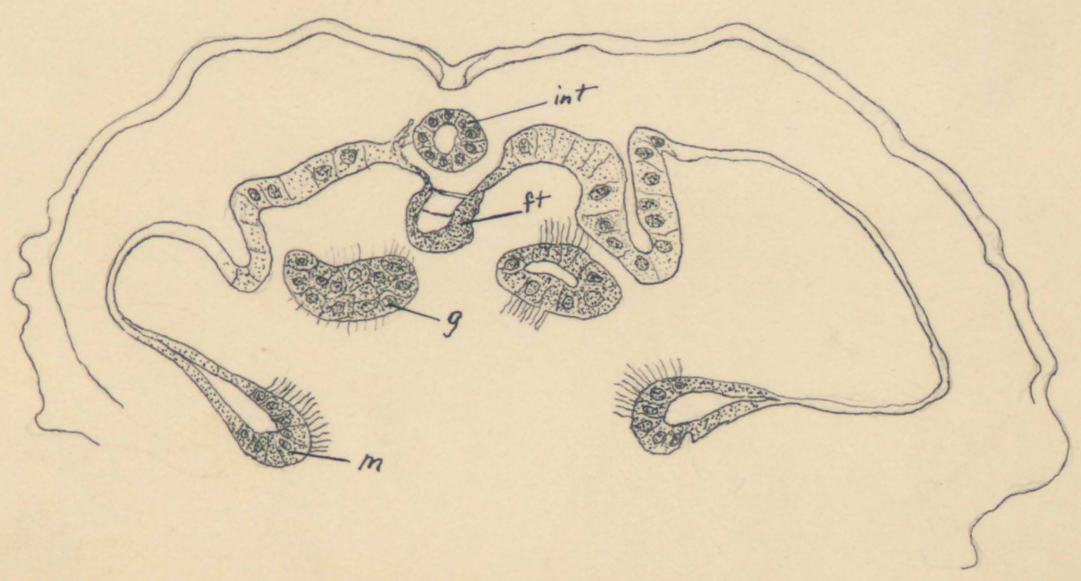

Fig 32




Fig 33



Fig 34

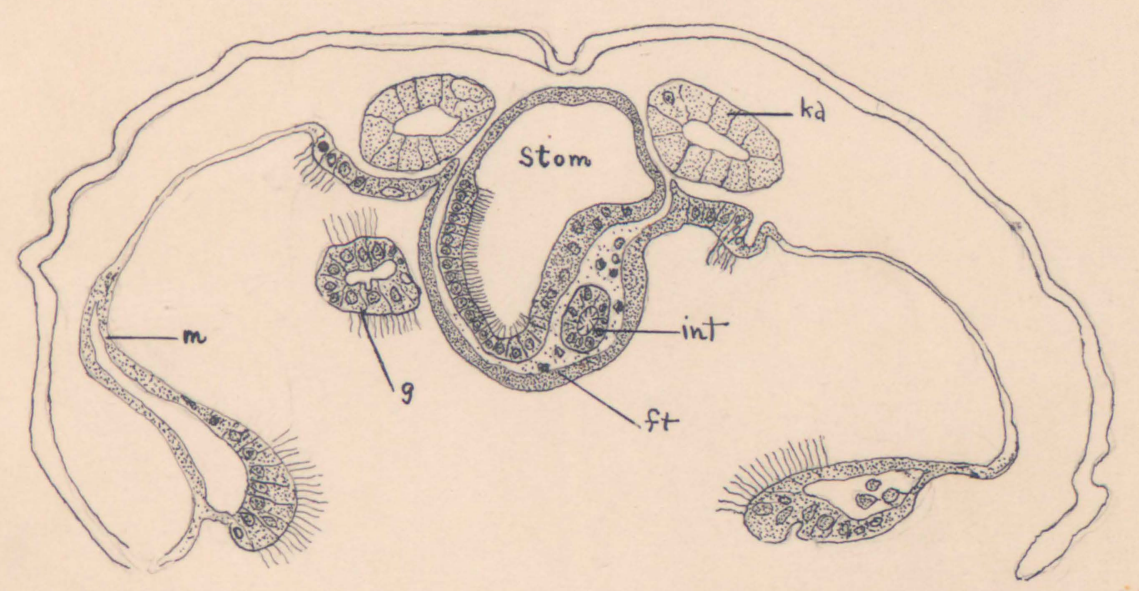

Fig 35




rale XIV

Fig. 36

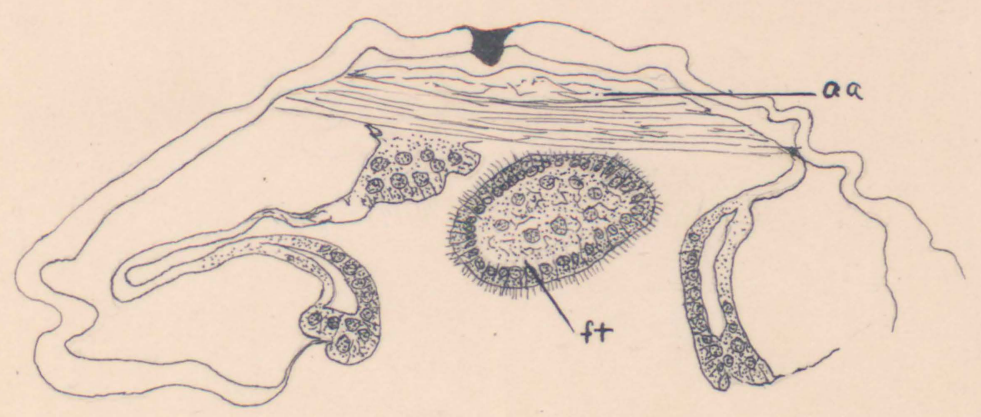

EiAimartin 
UNIVERSITY OF MISSOURI

Columbia

ZOOLOGICAL LABORATORY

May ISth, I9I6.

Dean Walter Miller,

University of Missouri.

My dear Dean Miller:- I have examined the thesis of

Mr. E A. Martin, which is herewith submitted, and find it

satisfactory.

Very truly yours,

M. P. lasts

Title:- "Some Observations on the Life History of Strophitus edentulus" 


\section{UnIVERSITY OF MisSOURI \\ Columan}

May 19, 1916.

Dean Walter Miller,

Graduate School.

Dear Doctor Miller:-

I have read the thesis on

"Some Observations on the Iife History of

Strophitus Edentulus" by Earl Albert Martin.

I consider the paper as maintaining a satis-

factory standard in partial fulfillment of

the requirements for Master's Degree.

Yours very truly,

CWG/O.






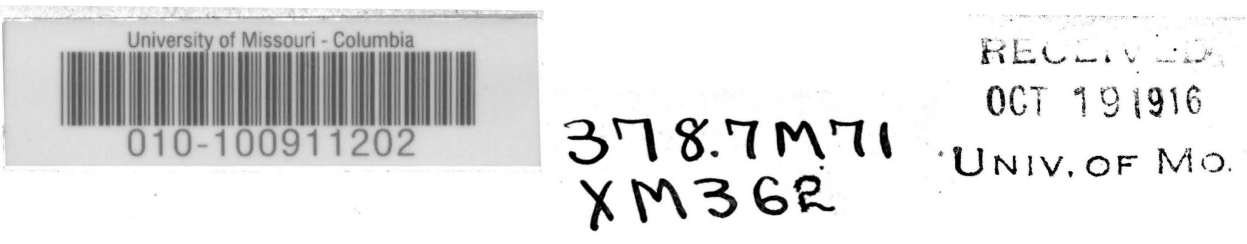


MU Libraries

Martin1916Scanspecs.txt

University of Missouri--Columbia

MU Theses and Dissertations (Pre-1920)

Local identifier

Capture information

Date captured

Scanner manufacturer

Scanner model

Scanning system software

optical resolution

Color settings

File types

Source information

Format

Content type

Source ID

Notes
Martin1916

2016-05-10

Zeutsche1

OS 15000

Omniscan v.12.4 SR4 (1947) 64-bit

$600 \mathrm{dpi}$

grayscale, 8 bit and color, 24 bit

tiff

Book

Text [with images]

010-100720668

Pages typed and single-sided.

Title page has perforated property stamp.

Ca11 number written on page after title page

Plates are pasted in.

A11 plates have purple ink property stamp.

University correspondence follows plate XIV.

Tiff compressed with LZW before conversion to pdf Adobe Photoshop CS5

$600 \mathrm{dp} i$

Grayscale and color

pdf

Grayscale pages cropped, canvassed, brightened.

Plates scanned in color and cropped.

$B\rceil$ ank pages removed. 